\title{
Migratory round-trip of individually identified humpback whales at the Strait of Magellan: clues on transit times and phylopatry to destinations
}

\author{
Ciclo migratorio de ballenas jorobadas individualizadas del estrecho de Magallanes: \\ indicios sobre la duración de la migración y filopatría en los destinos
}

\author{
JUAN J. CAPELLA ${ }^{1,2}$, JORGE GIBBONS ${ }^{3}$, LILIÁN FLÓREZ-GONZÁLEZ ${ }^{1}$, MARTHA LLANO ${ }^{4,1}$, \\ CARLOS VALLADARES ${ }^{2}$, VALERIA SABAJ ${ }^{5}$ \& YERKO A. VILINA ${ }^{2,6,7}$ * \\ ${ }^{1}$ Fundación Yubarta, Carrera 24F Oeste 3-110, Apartado Aéreo 33141, Cali, Colombia \\ 2 Whale Sound Limitada, Avenida España 666, Punta Arenas, Chile \\ ${ }^{3}$ Instituto de la Patagonia, Universidad de Magallanes, Punta Arenas, Chile \\ ${ }^{4}$ Fundación Sentir, Medellín, Colombia \\ ${ }^{5}$ Programa de Biología Celular y Molecular, Instituto de Ciencias Biomédicas, Facultad de Medicina, \\ Universidad de Chile. Santiago, Chile \\ ${ }^{6}$ Facultad de Medicina Veterinaria, Universidad Santo Tomás, Calle Ejército 146, Santiago, Chile \\ ${ }^{7}$ Centre of Advanced Studies in Biodiversity (CASEB), Pontificia Universidad Católica de Chile \\ * e-mail for correspondence: yvilina@santotomas.cl
}

\begin{abstract}
Humpback whales undertake seasonal migration between productive high-latitude areas where they feed in summer and low-latitude tropical waters where mating and calving occur during winter. In the eastern south Pacific, the species breeds off Colombia and Ecuador, and feeds primarily in the western Antarctic Peninsula and in the waters of the Strait of Magellan (SM), recently described as a new feeding ground for humpback whales. Comparison of fluke photographs of 62 individuals from the SM obtained during the austral summer from 1999 to 2005 and 1,042 individuals from Colombia, provided conclusive matches for six individuals, with an overall interchange index of 0.093 . Eight migratory trips between summer and winter grounds were registered for four whales during a complete migratory round-trip in consecutive years. The minimum distance traveled in a one-way trip ranged from 6,650 to $7,000 \mathrm{~km}$. The duration of the two fastest trips between these migratory destinations was 88 and 99 days, with a mean speed of migration of 76 and $67 \mathrm{~km}$ day $^{-1}$ respectively. Five of the whales present in both areas were males and three mitochondrial DNA haplotypes were identified: EM-1 for three individuals, EM-2 for two and EM-3 for the last one, all of which have been previously described for humpback whales from Colombia. All six individuals were seen several days in each season in the SM (as many as 39 days in one case), with an average stay of $72 \pm 40$ days $(\mathrm{n}=20)$ per year, ranging from 3 to 125 days. On average, each of the six individuals was seen in the SM during $71 \pm$ $18 \%$ of the seven monitored summers. Three individuals were re-sighted in the SM six out of the seven surveyed years, during four to six consecutive years. These results provide the first direct evidence to include humpback whales that feed in the Strait of Magellan as part of the eastern south Pacific population of whales that feed off Colombian waters.
\end{abstract}

Key words: Colombia, humpback whales, migration, photo-identification, Strait of Magellan.

\section{RESUMEN}

La ballena jorobada migra estacionalmente entre latitudes altas donde se alimenta en verano y latitudes bajas donde cría y se aparea en invierno. En el Pacífico sureste, la especie se reproduce en Colombia y Ecuador y se alimenta principalmente al oeste de la península Antártica, y en el estrecho de Magallanes (EM) recientemente descrito como nueva área de alimentación. Al comparar las fotografías de las colas de 62 ballenas individualizadas en el EM durante el verano austral entre 1999 y 2005 con 1.042 individuos de Colombia, se encontró a seis individuos comunes, lo que representa un Indice de Intercambio migratorio de 0,093. Se registraron ocho migraciones para cuatro de estas ballenas entre el EM y Colombia en el ciclo migratorio de años consecutivos. La distancia mínima recorrida en una sola dirección varió entre 6.650 y $7.000 \mathrm{~km}$. La duración de los dos viajes más rápidos registrados entre estos dos destinos fue de 88 y 99 días, con una velocidad promedio de migración de 76 y $67 \mathrm{~km} \mathrm{día}^{-1}$ respectivamente. Cinco de las seis ballenas comunes entre las áreas fueron machos. Entre las seis ballenas se encontraron tres haplotipos de ADN 
mitocondrial todos descritos previamente en ballenas jorobadas de Colombia: tres ballenas con el haplotipo EM-1, dos con el EM-2 y uno con el EM-3. Los seis individuos se avistaron reiteradamente en el EM (hasta 39 días en una estación en un caso), con una permanencia promedio de $72 \pm 40$ días $(\mathrm{n}=20)$ por año y un rango entre 3 y 125 días. En promedio, estas seis ballenas se vieron durante el $71 \pm 18 \%$ de las siete temporadas muestreadas en el EM y tres se registraron seis de lo siete años estudiados, por 4-6 años consecutivos. Esta es la primera evidencia directa para incluir las ballenas jorobadas que se alimentan en el estrecho de Magallanes como parte de la población del Pacífico sureste que se reproduce en aguas colombianas.

Palabras clave: Colombia, ballenas jorobadas, migración, foto identificación, estrecho de Magallanes, ADNmt.

\section{INTRODUCTION}

Humpback whales, Megaptera novaeangliae (Borowski 1781), undertake the longest known migration to any mammal (Stone et al. 1990, Clapham \& Mead 1999). This species inhabits all major ocean basins, and long-distance seasonal migration takes place between productive high-latitude areas where whales feed in the summer and fall, and low-latitude tropical waters where mating and calving occur during winter and spring (Mackintosh 1965). Photographic identification of individual humpback whales has established and confirmed migratory movements all over the world (Kaufman et al. 1990, Stone et al. 1990, Darling \& Cerchio 1993, Gill \& Burton 1995, Darling et al. 1996, Stevick et al. 1998, 2003).

The migratory destinations of humpback whales in the southeastern Pacific (Area I stock for International Whaling Commission) are partially known. Available information has been gathered from studies based on whaling data (Townsend 1935, Mackintosh 1942, Clarke 1962), and more recently on the identification by naturally marked individuals and on mitochondrial DNA (mtDNA) sequence analysis (Stone et al. 1990, Baker et al. 1998, FlórezGonzález et al. 1998, Olavarría-Barrera 1999, Caballero et al. 2001, Stevick et al. 2004). The main summer feeding ground, as presently known, for the southeastern Pacific humpback whale stock that breeds off Colombia and Ecuador (Flórez-González 1991, Scheidat et al. 2000, Félix \& Haase 2001a), extends along the western coast of the Antarctic Peninsula (WAP) (Omura 1953, Mackintosh 1965, Stone et al. 1990, Stevick et al. 2004), south to the Antarctic Convergence. These summer and winter final migratory destinations are $8,500 \mathrm{~km}$ away from each other (Stone et al. 1990). The cold inshore waters of western South America, located in the southern Patagonian fjords and the Strait of Magellan (SM), have recently been described as a summer feeding ground for humpback whales (Gibbons et al. 1998, Gibbons 2003). In accordance with the last report (Gibbons et al. 2003), there is historical evidence of the presence of whales near Carlos III Island in the $\mathrm{SM}$, dated from the $16^{\text {th }}$ century. This species reaches significant concentrations around Carlos III Island from summer to autumn, period during which the authors have also frequently observed an important presence of prey species for humpback whales, such as schooling fishes (herring, Sprattus fueguensis) and krill (Euphausia sp.). This feeding ground is characterized by (1) containing adults and calves, $13 \%$ of the 62 identified whales are mothers accompanied by calves born that year (J. Capella unpublished data), (2) group sizes with a mode of two individuals (Gibbons et al. 2003), and (3) a sex ratio of 1:1 (V. Sabaj unpublished data)

At present, there is no published data about conclusive wintering origins for individual humpback whales sighted during summer months in the SM. However, indirect data based on pigmentation pattern of flukes (Gibbons et al. 2004) and mtDNA markers (Guerrero 2003) suggest an affinity between humpback whales from the SM and Colombia. Current available evidence indicates that there is no migratory connection between humpback whales from WAP and the SM (Acevedo 2006) or the Southwestern Atlantic Ocean (Brazil) (Stevick et al. 2004, Zerbini et al. 2006). Neither is there any photographic evidence connecting humpback whales from breeding grounds in Brazil to those observed in southwestern America (Stevick et al. 2004).

If humpback whales of the SM belong to the southeast Pacific population, then some individual whales must be common to both the 
SM and the main breeding ground from the eastern Pacific Ocean, i.e. the Colombian waters. In this paper we document the migratory destination of six humpback whales from SM to the wintering grounds in Colombia, an estimation of the duration of migration and the site fidelity to these two migratory destinations. We discuss these findings in the context of clues for a short migratory cycle for the Southeast Pacific humpback whales related to strong phylopatry to this newly discovered summer ground.

\section{MATERIAL AND METHODS}

\section{Study locations}

In high latitudes, the study area encompasses the central sector of the SM around Carlos III Island $\left(53^{\circ} 37^{\prime} \mathrm{S}, 72^{\circ} 21^{\prime} \mathrm{W}\right)$, including Whale Sound, Tortuoso Passage, and Jerónimo and Barbara Channels. The study area covers approximately $1,150 \mathrm{~km}^{2}$ of marine channels where humpback whales feed. Waters are up to $600 \mathrm{~m}$ in depth, with a maximum tidal range of less than $4 \mathrm{~m}$, strong current flows and an average surface water temperature ranging between 6 and $8{ }^{\circ} \mathrm{C}$. The low-latitude study area is situated along the western coast of Colombia, within the waters of the continental shelf (depth $<200 \mathrm{~m}$ ) and has an average surface water temperature ranging between 26 and $28{ }^{\circ} \mathrm{C}$ (Flórez-González 1991). Three main wintering aggregations of humpback whales are recognized along the coast with some degree of interchange among them (Recalde 2005):
Gorgona Island (GI) in the south sector $\left(2^{\circ} 58^{\prime}\right.$ $\mathrm{N}, 78^{\circ} 10^{\prime} \mathrm{W}$ ), Malaga Bay (MB) along the central coast $\left(4^{\circ} \mathrm{N}, 77^{\circ} 10^{\prime} \mathrm{W}\right)$ and Tribugá Gulf (TG) in the north $\left(6^{\circ} \mathrm{N}, 77^{\circ} 30^{\prime} \mathrm{W}\right)$.

\section{Data collection and management}

Searches for humpback whales were carried out on small vessels in each study location, with a minimum of two observers and in good weather conditions (Beaufort Sea state $\leq 3$ ). Sampling in the SM was undertaken during 250 vesseldays from 1999 to 2005, between January and April-May of each year, except 2004, when it continued until June. Boat surveys in Colombia were carried out during the austral winter and spring months (July to October-November) during 1,132 vessel-days from 1986 to 2003 (Table 1) (Fundación Yubarta, Fundación Sentir). Field methods are as described in Flórez-González (1991).

For each sighting, the date was recorded and attempts were made to take photographs of flukes and obtain skin samples of the individuals. Photographs of ventral flukes were taken with $35 \mathrm{~mm}$ cameras or digital cameras equipped with $70-210 \mathrm{~mm}$ or $300 \mathrm{~mm}$ lenses, and ISO 100, 200 and 400 print or slide film. Photographs without a minimum photographic quality were excluded. Skin biopsies were collected in the SM using a $30 \mathrm{~mm}$ long bolt with an $8 \mathrm{~mm}$ diameter hollow stainless steel tip attached to an arrow propelled by a crossbow (Lambertsen 1987). Skin biopsies were maintained in a solution of $20 \%$ DMSO saturated with $\mathrm{NaCl}$ at $7{ }^{\circ} \mathrm{C}$ for later DNA analysis.

Sampling periods, total effort (Vessel-days), total number of humpback whales identified in Chile and Colombia from 1986 to 2005 (Ni), and global index of phylopatry (Ph)

Periodos de muestreo (en años), esfuerzo total en días de embarcación (Vessel-days), número de ballenas jorobadas identificadas en Chile y Colombia entre 1986 y 2005 (Ni), e índice global de filopatría (Ph)

\begin{tabular}{lllcrr}
\hline Region & Area & Sampling years & Vessel-days & Ni & Ph \\
\hline Chile & Strait of Magellan & $1999-2005$ & 250 & 62 & 1.34 \\
& & & & 722 & 0.37 \\
Colombia & Gorgona Island & $1986-1995,1997,1999,2003$ & 764 & 354 & 0.53 \\
& Malaga Bay & $1993-1998,2000-2001$ & 313 & 61 & 0.26 \\
& Tribuga Gulf & $1997-1998,2000-2001$ & 55 & & \\
& & &
\end{tabular}


Identifications were made for each one of the four localities (SM, GI, MB and TG) (Table 1).

Duration of migration was defined as the time elapsed from the last date of sighting in a seasonal habitat until the first date sighted in the next migratory destination.

\section{Identification and matching}

Humpback whales were individually identified from photographs of the unique patterns of ventral fluke pigmentation (Katona \& Whitehead 1981). Matches of humpback whales were found by comparing a collection of 62 adult individuals identified in the SM (Capella \& Gibbons unpublished catalog) with a total collection of 1,042 unique individual whales in Colombia. Catalogs from Colombia include Gorgona Island (722), Malaga Bay (354) (Fundación Yubarta unpublished catalog) and Tribuga Gulf (61) (Fundación Sentir and Fundación Yubarta unpublished catalogs), 95 of which are common for two or the three localities.

\section{Migratory connection and phylopatry}

Interchange index $\left(\mathrm{I}_{\mathrm{bf}}\right)$ between the $\mathrm{SM}$ and Colombia was calculated, as previously described (e.g., Baker et al. 1985, Urbán et al. 1999, Calambokidis et al. 2001):

$$
I_{b f}=\left(m_{b f} /\left[n_{b} \times n_{f}\right]\right) \times 1000,
$$

where $m_{b f}$ is the number of individual whales seen both in Colombia and the SM, $\mathrm{n}_{\mathrm{b}}$ is the number of individuals from Colombia and $n_{\mathrm{f}}$ is the number of individuals from the SM. This index is basically the inverse of the Petersen capture-recapture index. A high value of this index reflects a high probability of recapture due to either a small population or a high interchange of individuals between the two regions.

An index of phylopatry $(\mathrm{Ph})$ was defined as a global rate of recapture. It was calculated to provide a relative quantification of the amount of annual return to specific locations in Colombia and the SM:

$$
\mathrm{Ph}=(\mathrm{k}-\mathrm{n}) / \mathrm{n},
$$

where $\mathrm{k}$ is the total number of whales identified along the period and $\mathrm{n}$ is the sum of newly identified individuals each year (not photographed in previous years) for the whole period. A low value in this index indicates a low annual return or low phylopatry to a determined migratory destination, while a high value reflects a high phylopatry.

\section{mtDNA haplotypes and sex determination}

Mitochondrial DNA haplotypes were determined from skin biopsies for whales matched between the SM and Colombia. A 441 base pair (bp) fragment near the 5' end of the mtDNA control region (Baker et al. 1993) was amplified by the Polymerase Chain Reaction (PCR) (Saiki et al. 1988) using the following primers designed with the program Primer3 (Rozen \& Skaletsky 2000): "Wh2F" (5' TTG TAC AAT AAC GAC AGG GCG AC 3') and "Wh2R" (5' TTT AAA TTA ATA TGG CCC TGA AG 3'). Cycle conditions consisted in a preliminary denaturing period of 2 minutes at $94{ }^{\circ} \mathrm{C}$ followed by 35 cycles of denaturation for 30 seconds at $94{ }^{\circ} \mathrm{C}$, primer annealing for 30 seconds at $60{ }^{\circ} \mathrm{C}$, and polymerase extension for 90 seconds at $72{ }^{\circ} \mathrm{C}$. A final extension period for $15 \mathrm{~min}$ at $72{ }^{\circ} \mathrm{C}$ was included. Both strands of cleaned PCR products were sequenced on an ABI-310 Genetic Analyzer (Applied Biosystems Inc., Foster, California, USA) using the Big Dye terminator v1.1 sequencing kit (Applied Biosystems Inc., Foster, California, USA). Sequences were checked visually for possible sequencing errors and corrected manually. Sequences were aligned and edited using the program BioEdit (Hall 1999). For comparative analysis with previously studied humpback whales from Colombia, sequences were truncated to correspond with a $283 \mathrm{bp}$ segment (Baker et al. 1998, Caballero et al. 2001).

The sex of whales was identified by amplification via the PCR and subsequent Taq I digestion of a homologous region of the $\mathrm{X}$ and Y chromosomes (Palsbøll et al. 1992). Taq I restriction fragments of the amplified DNA were separated by gel electrophoresis in $3 \%$ agarose at $200 \mathrm{~V}$, and visualized and photographed under UV. The female pattern is characterized by the presence of two bands (439-bp and 182-bp), whereas males show an additional band of 621-bp. 


\section{RESULTS}

\section{Matches and transit times}

Comparison of photographs resulted in conclusive matches of six individuals between the SM and Colombia (Fig. 1) which established a minimum of eleven trips (Table 2 ). The markings of the fluke for individuals EMa-020, EMa-018 and EMa-033, shown in the accompanying photographs (Fig. 1), showed little or no changes during the intervals between the first and last sightings which ranged from ten to fourteen years.

Four whales were documented moving between summer and winter grounds in a complete migratory round-trip during one year (Table 2 and 3). One whale (EMa-033) was observed at two of our study areas along the Colombian coast in different years. The duration of migration between these migratory destinations varied from 88 days between GI and the SM in 2003-2004 to 265 days between the SM and GI in 2003 (Table 3). The minimum lineal distance between migratory destinations ranged from $6,650 \mathrm{~km}$ for the $\mathrm{SM}$ to GI to $7,000 \mathrm{~km}$ for the SM to TG (Table 3). The two fastest trips recorded here (88 and 99 days from GI to the SM) represent a mean speed of migration of 76 and $67 \mathrm{~km} \mathrm{day}^{-1}$ respectively (Table 4).

\section{Sex and mtDNA haplotypes}

The six matched whales correspond to five males and one female. Among them, three mtDNA haplotypes were identified: EM-1 for three individuals, EM-2 for two and EM-3 for the last one (Table 2).

The alignment of the three haplotypes of the SM Humpback whales with those published revealed that the three of them have been described in Colombia (Baker 1998: Genbank accession numbers AF068069, AF068067 and AF068078; Caballero 2001). They have also been described for the Antarctic Peninsula (AP) feeding ground (Olavarría-Barrera 1999, Olavarría-Barrera et al. 2000). EM-1 is the most frequent haplotype described both in Colombia and AP (Olavarría-Barrera et al. 2000); EM-2 and EM-3 haplotypes have not been described at any other population of Humpback whales analyzed. EM-1 has also been reported from north Pacific humpback whales (Olavarría-Barrera et al. 2000).

\section{Destination fidelity and migratory connection}

There is a higher occurrence (number of sightings of specific individuals on different days within a year) and a greater site fidelity to the high-latitude destination compared with the low-latitude destination for all six individuals. They were seen in the SM repeatedly in a particular year (as many as 39 days), with an average stay of $72 \pm 40$ days $(n=20)$, ranging from 3 to 125 days (Table 2). On average, each of the six individuals was seen in the SM during $71 \pm 18 \%$ of the seven summers sampled. Three individuals (EMa-003, EMa004 and EMa-020) were re-sighted in the SM six out of seven surveyed years, and during four to six consecutive years (Table 2). In Colombia, five of these individuals were seen only once or twice in total and one individual only (EMa-033) was seen three years out of 17 surveyed years (Table 2). The total photoidentified individuals of humpback whales from the SM and Colombia showed significant differences in the level of annual return, with a mean index of phylopatry of $\mathrm{Ph}=1.78 \pm 1.35$ in a year by year analysis for the six-year period in the $\mathrm{SM}$, in comparison to $\mathrm{Ph}=0.59 \pm$ 0.72 for the whole region in Colombia over 17 years (Mann-Whitney U-test, $\mathrm{U}=10.0, \mathrm{p}=$ $0.017)$. The global phylopatry index with the total cumulative data was $\mathrm{Ph}=1.34$ for the $\mathrm{SM}$ and $\mathrm{Ph}=0.26$ for $\mathrm{TG}, \mathrm{Ph}=0.37$ for $\mathrm{MB}$ and $\mathrm{Ph}$ $=0.53$ for GI in Colombia (Table 1 and 5).

The six humpback whales of the SM matched with Colombia provided an overall Interchange Index of 0.093 (Table 6). The highest degree of interchange was with TG $(0.260)$ as a result of one match, followed by MB (0.091) with two matches and GI (0.089) with four matches (see Table 2 for matches).

\section{DISCUSSION}

These results provide the first direct evidence to include humpback whales that feed in the Strait of Magellan as part of the Southeast Pacific population belonging to stock $G$ breeding ground for the southern hemisphere (IWC 1998). In addition to the photographic 


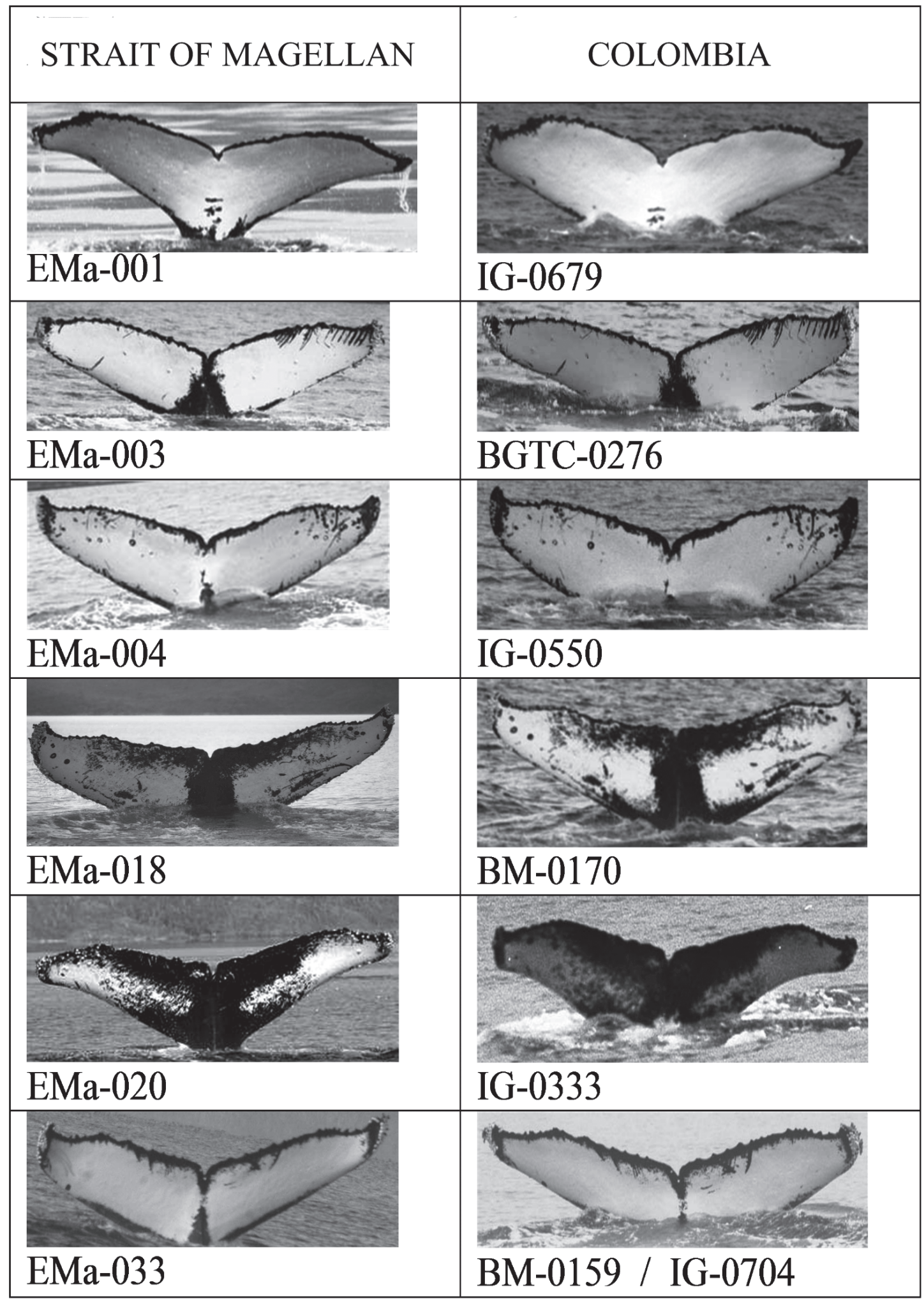

Fig. 1: Fluke photographs of the six individual humpback whales matched between the Strait of Magellan and Colombia.

Fotografías de las colas de seis ballenas jorobadas registradas tanto en el estrecho de Magallanes como en Colombia. 
TABLE 2

Matches of humpback whales identified between 1999 and 2005 in the Strait of Magellan and in their wintering grounds off Colombia. Details of sex, mitochondrial DNA haplotypes, dates of the first and the last observation by year and number of days of sightings by locality are shown

Ejemplares de ballena jorobada identificados en el estrecho de Magallanes entre 1999 y 2005 comunes con Colombia. Se muestra el detalle de haplotipo de ADN mitocondrial, fechas de la primera y última observación en el año y el número de días de avistamiento por localidad

\begin{tabular}{|c|c|c|c|c|c|c|c|c|c|}
\hline \multirow[b]{2}{*}{$\begin{array}{l}\text { Whale } \\
\text { IDnumber }\end{array}$} & \multirow[b]{2}{*}{$\begin{array}{c}\text { Sex } \\
\text { mtDNA } \\
\text { haplotype }\end{array}$} & \multicolumn{4}{|c|}{ Strait of Magellan } & \multicolumn{4}{|c|}{ Colombia } \\
\hline & & Year & $\begin{array}{c}\text { First } \\
\text { obser- } \\
\text { vation }\end{array}$ & $\begin{array}{c}\text { Last } \\
\text { obser- } \\
\text { vation }\end{array}$ & $\begin{array}{l}\text { Number } \\
\text { of days }\end{array}$ & Year & $\begin{array}{l}\text { First } \\
\text { obser- } \\
\text { vation }\end{array}$ & $\begin{array}{c}\text { Last } \\
\text { obser- } \\
\text { vation }\end{array}$ & $\begin{array}{l}\text { Number } \\
\text { of days }\end{array}$ \\
\hline \multirow[t]{4}{*}{ EMa-001 } & MEM-1 & 1999 & 15-Jan & - & 1 & & & & \\
\hline & & 2001 & 21-Feb & - & 1 & & & & \\
\hline & & 2003 & 29-Mar & - & 1 & $2003^{(1)}$ & $12-\mathrm{Oct}$ & - & 1 \\
\hline & & 2004 & 8-Jan & 25-Mar & 6 & & & & \\
\hline \multirow[t]{6}{*}{ EMa-003 } & MEM-1 & 1999 & 15-Jan & 10-May & 3 & & & & \\
\hline & & 2001 & 13-Feb & - & 1 & 2001 & 22-Aug & - & 1 \\
\hline & & 2002 & 7-Feb & 9-Feb & 2 & & & & \\
\hline & & 2003 & 15-Jan & $16-\mathrm{Feb}$ & 13 & & & & \\
\hline & & 2004 & 19-Jan & 16-May & 29 & & & & \\
\hline & & 2005 & 3-Jan & 5-Apr & 39 & & & & \\
\hline \multirow[t]{6}{*}{ EMa-004 } & FEM-1 & 1999 & 22-Jan & - & 1 & & & & \\
\hline & & 2000 & 20-Apr & - & 1 & & & & \\
\hline & & 2002 & $18-F e b$ & - & 1 & & & & \\
\hline & & 2003 & 22-Jan & 23-Feb & 9 & $2003^{(1)}$ & 22-Aug & - & 1 \\
\hline & & 2004 & 30-Jan & 22-Apr & 4 & & & & \\
\hline & & 2005 & 21-Jan & 20-Mar & 2 & & & & \\
\hline \multirow[t]{6}{*}{ EMa-018 } & MEM-2 & - & & & & $1995^{(2)}$ & 30-Aug & - & 1 \\
\hline & & 2000 & $10-F e b$ & - & 1 & & & & \\
\hline & & 2002 & 6-Feb & 9-Feb & 3 & & & & \\
\hline & & 2003 & 24-Jan & 21-Feb & 4 & & & & \\
\hline & & 2004 & 7-Feb & 18-May & 16 & & & & \\
\hline & & 2005 & 30-Dec & 11-Apr & 12 & & & & \\
\hline \multirow[t]{8}{*}{ EMa-020 } & MEM-2 & - & & & & $1991^{(1)}$ & 1-Sep & - & 1 \\
\hline & & - & & & & $1993^{(1)}$ & 13-Aug & - & 1 \\
\hline & & 2000 & 10-Feb & - & 1 & & & & \\
\hline & & 2001 & 13-Feb & - & 1 & & & & \\
\hline & & 2002 & 6-Feb & 9-Feb & 2 & & & & \\
\hline & & 2003 & 14-Feb & 29-Mar & 6 & & & & \\
\hline & & 2004 & $5-\mathrm{Feb}$ & 9-Jun & 32 & & & & \\
\hline & & 2005 & 21-Jan & 9-Apr & 16 & & & & \\
\hline \multirow[t]{5}{*}{ EMa-033 } & MEM-3 & - & & & & $1995^{(2)}$ & 23-Aug & 20-Sep & 2 \\
\hline & & - & & & & $1996^{(2)}$ & 31-Aug & 22-Sep & 2 \\
\hline & & 2003 & 22-Jan & 9-Feb & 8 & $2003^{(1)}$ & $2-\mathrm{Nov}$ & 3-Nov & 2 \\
\hline & & 2004 & 11-Feb & 9-May & 16 & & & & \\
\hline & & 2005 & 14-Feb & $18-\mathrm{Feb}$ & 2 & & & & \\
\hline
\end{tabular}

In Colombia: (1) Gorgona Island; (2) Malaga Bay; ${ }^{(3)}$ Tribuga Gulf 
TABLE 3

Duration and distance traveled by individual humpback whales in round-trip migration among the Strait of Magellan and wintering destinations in Colombian coasts

Duración y distancia recorrida por ballenas jorobadas individualizadas en un ciclo migratorio completo entre el estrecho de Magallanes y Colombia

\begin{tabular}{|c|c|c|c|}
\hline Whale ID number & Migratory destinations inconsecutive years & Duration of the trip(days) & Distance traveled $(\mathrm{km})^{*}$ \\
\hline \multirow[t]{2}{*}{ EMa-001 } & Strait of Magellan - Colombia ${ }^{(1)}$ (2003) & 197 & 6,650 \\
\hline & Colombia ${ }^{(1)}$ - Strait of Magellan (2004) & 88 & 6,650 \\
\hline \multirow[t]{2}{*}{ EMa-003 } & Strait of Magellan - Colombia ${ }^{(2)}$ (2001) & 190 & 7,000 \\
\hline & Colombia ${ }^{(2)}$ - Strait of Magellan (2002) & 169 & 7,000 \\
\hline \multirow[t]{2}{*}{ EMa-004 } & Strait of Magellan - Colombia (1) (2003) & 180 & 6,650 \\
\hline & Colombia ${ }^{(1)}$ - Strait of Magellan (2004) & 161 & 6,650 \\
\hline \multirow[t]{2}{*}{ EMa-033 } & Strait of Magellan - Colombia (1) (2003) & 265 & 6,650 \\
\hline & Colombia ${ }^{(1)}$ - Strait of Magellan (2004) & 99 & 6,650 \\
\hline
\end{tabular}

*minimum lineal distance among localities; ${ }^{(1)}$ Gorgona Island, Colombia; ${ }^{(2)}$ Tribuga Gulf, Colombia

TABLE 4

Comparative information on distance traveled, duration of the trip, mean speed of the trip for the two fastest individuals recorded in this work and method of recording for different migratory connections of humpback whales. Values were obtained and calculated from data sources

Comparación de la distancia recorrida, duración de la migración, velocidad promedio de viaje de los dos individuos más rápidos registrados en este trabajo y método de registro para diferentes conexiones migratorias de las ballenas jorobadas Valores obtenidos y calculados a partir de los datos de las fuentes

\begin{tabular}{llcccl}
\hline Trip & Method & $\begin{array}{c}\text { Distance } \\
\text { traveled } \\
(\mathrm{km})\end{array}$ & $\begin{array}{c}\text { Duration } \\
\text { of the trip } \\
(\mathrm{days})\end{array}$ & $\begin{array}{c}\text { Migration } \\
\text { rate } \\
\left(\mathrm{km} \mathrm{day}^{-1}\right)\end{array}$ & Source \\
\hline Antarctic - East Australia & Photo-ID & 3,500 & 216 & 16 & Kaufman et al. (1990) \\
Costa Rica - California & Photo-ID & 5,200 & 218 & 24 & Steiger et al. (1991) \\
California - Costa Rica & Photo-ID & 5,200 & 171 & 30 & Steiger et al. (1991) \\
Japan - Vancouver & Photo-ID & 7,900 & 152 & 52 & Darling et al. (1996) \\
Dominican Republic - Cape Cod (USA) & Photo-ID & 2,351 & 43 & 55 & Clapham \& Mattila (1988) \\
Alaska - Hawaii & Photo-ID & 4,400 & 79 & 56 & Baker et al. (1985) \\
Brazil - South west Atlantic & Satellite telemetry & 3,640 & 60 & 61 & Zerbini et al. (2006) \\
Antarctic - Colombia & Photo-ID & 8,350 & 131 & 64 & Stone et al. (1990) \\
Colombia - Strait of Magellan & Photo-ID & 6,650 & 99 & 67 & This study \\
Colombia - Strait of Magellan & Photo-ID & 6,650 & 88 & 76 & This study \\
Puerto Rico - Cape Cod (USA) & Photo-ID & 2,684 & 34 & 79 & Clapham \& Mattila (1988) \\
Brazil - South west Atlantic & Satellite telemetry & 3,720 & 42 & 89 & Zerbini et al. (2006) \\
Mexico - Hawaii & Photo-ID & 4,700 & 49 & 96 & Darling \& Cerchio (1993) \\
Alaska - Hawaii & Photo-ID & 4,400 & 39 & 113 & Gabriele et al. (1996) \\
\hline & & & & &
\end{tabular}




\section{TABLE 5}

Global phylopatry index $(\mathrm{Ph})$ for different areas in wintering and summering regions of humpback whales. Values were calculated from data sources

Índice de filopatría global $(\mathrm{Ph})$ para diferentes áreas de las regiones de verano e invierno de ballenas jorobadas. Valores calculados a partir de los datos de las fuentes

\begin{tabular}{|c|c|c|c|}
\hline & Regions & $\mathrm{Ph}$ & Source \\
\hline \multicolumn{4}{|l|}{ Wintering areas } \\
\hline & Ecuador & 0.01 & Félix \& Haase (2001c) \\
\hline & West Indies & 0.04 & Smith et al. (1999) \\
\hline & Hawaii & 0.13 & Glockner-Ferrari \& Ferrari (1990) \\
\hline & Hawaii & 0.18 & Baker et al. (1986) \\
\hline & Hawaii & 0.24 & Perry et al. (1990) \\
\hline & Mexico & 0.24 & Urbán et al. (1999) \\
\hline & New Caledonia & 0.38 & Garrigue et al. (2001) \\
\hline & Colombia & 0.42 & This study \\
\hline & Japan & 0.47 & Darling \& Mori (1993) \\
\hline \multicolumn{4}{|l|}{ Summering areas } \\
\hline & Newfoundland & 0.08 & Katona \& Beard (1990) \\
\hline & Shumagin Island, Alaska & 0.22 & Witteveen et al. (2004) \\
\hline & Gulf of Saint Lawrence & 0.27 & Katona \& Beard (1990) \\
\hline & Greenland & 0.28 & Katona \& Beard (1990) \\
\hline & California & 0.63 & Calambokidis et al. (1990) \\
\hline & South east Alaska & 0.76 & Baker et al. (1986) \\
\hline & South east Alaska & 0.94 & Perry et al. (1990) \\
\hline & Strait of Magellan & 1.34 & This study \\
\hline & Gulf of Maine & 1.70 & Katona \& Beard (1990) \\
\hline & Gulf of Maine & 2.18 & Clapham et al. (1993) \\
\hline
\end{tabular}

matching and the round trip movements of individuals demonstrated here, the haplotypes of the mtDNA belonging to the six individual whales observed both in the SM and Colombian waters also support a strong affinity between those regions. The most common haplotype found in the SM population (V. Sabaj unpublished data) is the dominant one for Gorgona Island and Malaga Bay (Caballero et al. 2001) and it is also present, at a low frequency, in the North Pacific humpback whales (Olavarría-Barrera et al 2000, Caballero et al. 2001). Two of the three haplotypes described for the six matched individuals, as far as we know, have not been described in any population of humpback whales other than Colombia and Antarctic Peninsula, suggesting that this population is isolated from other Pacific populations. This finding is further supported by the high phylopatry index estimated for the SM population as compared to other parts of the world.

Several major migratory connections of humpback whale populations, based on the Interchange Index, have been reported worldwide, such as those between the Mexican coast and the west coast of the United States (California-Oregon-Washington, Urbán et al. 2000), and between Hawaii with SE Alaska and W Gulf of Alaska (Perry et al. 1990), as well as secondary connections, i.e., México-Prince William Sound (Alaska) and Hawaii-British Columbia (Calambokidis et al. 2001). In the Southeast Pacific the main migratory connection is between WAP with Colombia and Ecuador (Stevick et al. 2004), with similar values to those found among main destinations of other populations. The index of Interchange of 0.093 between the SM and Colombia, represents a migratory connection with an 
intermediate value, similar to the secondary migratory destinations for Hawaii, México and Dominican Republic (Katona \& Beard 1990, Urbán et al. 2000, Calambokidis et al. 2001).

Although our data is limited, it is concordant with the described presence of whales in Colombia from feeding grounds of west Antarctic Peninsula as well as SM. On the other side, given that only $10 \%$ of humpback whales photo-identified in the SM were found in Colombia, other breeding areas, such as Ecuador and Panamá, could be other wintering destinations for SM whales.

The transit registration of EMa-001 between the Strait of Magellan and Colombia in 88 days is the third fastest among the photoidentification data and intermediate among satellite telemetry data available for other parts of the world (Table 4). The only published information about transit time for the SE Pacific population is one photo-identified whale that swam $8,350 \mathrm{~km}$ from the Antarctic Peninsula to Gorgona Island in 131 days (Stone et al. 1990), equivalent to $64 \mathrm{~km} \mathrm{day}^{-1}$ (Table 4). Due to little coverage of the study areas, the resultant element of chance involved in reidentifying individuals and the impossibility of establishing erratic movements and changes in speed for whales, the use of photoidentification to study the movements of whales provides conservative estimates of migration duration and distance traveled. Methods such as the satellite telemetry have provided information with unprecedented accuracy about journeys of individual humpback whales in other populations, showing that none of the whales tagged traveled together, departure timing varied for a period of two months, and periods of both straight line and erratic movements existed (Mate et al. 1998, Zerbini et al. 2006). In the Southwest Atlantic for example, two humpback whales travelled 3,720 and $3,640 \mathrm{~km}$ through oceanic waters in a relatively direct pattern, at a mean speed of $89 \mathrm{~km}^{-1 a y}{ }^{-1}$ and $61 \mathrm{~km} \mathrm{day}^{-1}$, respectively (Table 4 ), and then moved erratically for several hundred kilometres during more than 75 days when they were already in feeding grounds (Zerbini et al. 2006) probably looking for food. Unlike the fastest

TABLE 6

Interchange Index between different migratory connection of breeding and feeding grounds of humpback whales. $\mathrm{m}_{\mathrm{bf}}$ : individuals matched between breeding and feeding grounds; $\mathrm{n}_{\mathrm{f}}$ : number of individuals identified in feeding grounds; $\mathrm{n}_{\mathrm{b}}$ : number of individuals identified in breeding ground.

Values obtained and calculated from data sources

Índice de Intercambio para diferentes conexiones migratorias entre áreas de reproducción y alimentación de ballenas jorobadas. $\mathrm{m}_{\mathrm{bf}}$ : individuos encontrados en sitios de alimentación y de apareamiento; $\mathrm{n}_{\mathrm{f}}$ : numero de individuos identificados en sitios de alimentación; $\mathrm{n}_{\mathrm{b}}$ : número de individuos identificados en sitios de apareamiento. Valores obtenidos y calculados a partir de los datos de las fuentes

\begin{tabular}{lccccc}
\hline Migratory connection & $\mathrm{m}_{\mathrm{bf}}$ & $\mathrm{n}_{\mathrm{f}}$ & $\mathrm{n}_{\mathrm{b}}$ & Interchange index & Source \\
\hline Mexico (coast) - Prince William Sound & 1 & 87 & 138 & 0.083 & Calambokidis et al. (2001) \\
Mexico (coast) - South east Alaska & 4 & 429 & 383 & 0.024 & Urbán et al. (2000) \\
Mexico (coast) - California-Oregon-Washington & 97 & 597 & 383 & 0.424 & Urbán et al. (2000) \\
Hawaii - British Columbia & 9 & 73 & 1,056 & 0.117 & Calambokidis et al. (2001) \\
Hawaii - South east Alaska & 82 & 464 & 634 & 0.279 & Perry et al. (1990) \\
Hawaii - West Gulf of Alaska & 17 & 95 & 634 & 0.282 & Perry et al. (1990) \\
Dominican Republic - Gulf of Maine & 32 & 505 & 975 & 0.065 & Katona \& Beard (1990) \\
Dominican Republic - Newfoundland & 157 & 1,443 & 975 & 0.112 & Katona \& Beard (1990) \\
Dominican Republic - Greenland & 17 & 154 & 975 & 0.113 & Katona \& Beard (1990) \\
Ecuador - West Antarctic Peninsula (AP) & 32 & 535 & 254 & 0.236 & Stevick et al. (2004) \\
Colombia - Antarctic Peninsula (WAP) & 14 & 535 & 79 & 0.331 & Stevick et al. (2004) \\
Colombia - Strait of Magellan & 6 & 62 & 1,042 & 0.093 & This study \\
\hline
\end{tabular}


trips between Hawaii and Alaska, Hawaii and México and Brazil and SW Atlantic (Darling \& Cerchio 1993, Gabriele et al. 1996, Zerbini et al. 2006) that occur in open sea, migration between the SM and Colombia covered a distance of 2,000 to $3,000 \mathrm{~km}$ longer than those previously mentioned (Table 4) and probably crossed through a set of more coastal sites potentially appropriate for feeding and or reproduction. The fastest migration speed of EMa-001 on 2004 between the SM and Colombia (76 km day ${ }^{-1}$ on average) and the second fastest EMa-033 on the same year (67 $\mathrm{km} \mathrm{day}^{-1}$ on average), correspond to a speed range for straight line movements of migrating whales in the SW Atlantic (61 to $89 \mathrm{~km} \mathrm{day}^{-1}$ ) (Table 4). The registered time of migration for these two individuals suggests, then, to direct trips without erratic movements. On the contrary, erratic movements could explain the longest durations registered for the same individuals on 2003 (EMa-001:197 days and EMa-033:265 days). Validity of these suggestions will require the use of different techniques as the previously mentioned satellite telemetry.

Considerable site fidelity exists among the six migrating individual whales at the feeding grounds of the SM. Values estimated for their residence times and fidelity are representative of this population: humpback whales stayed in the SM during $57 \pm 43$ days $(n=102)$ on average and $60 \%$ of the 62 individuals identified returned for two to six years ( $\mathrm{J}$. Capella unpublished data). The global Phylopatry Index for the SM is higher than any one in wintering grounds and is one of the highest worldwide for summering areas (Table 5). However, some movement outside the SM must occur because there is considerable variation in residence times among individuals (2 to 155 days) (J. Capella unpublished data). There are frequent sightings of humpback whales in the Corcovado Gulf area in summer, about $1,000 \mathrm{~km}$ north of the SM on the Pacific coast (Gibbons \& Capella 2006) and one individual recorded in Carlos III Island was also sighted in Canal Wide, Patagonian fjords region, $365 \mathrm{~km}$ north (Gibbons et al. 2003). In contrast, tropical wintering ranges on the west coasts of South America appear to be characterized by a high turnover of individuals with interchange among areas (Flórez-
González et al. 1998, Recalde 2005) and a weaker site fidelity, a common fact in breeding areas worldwide (Table 5). The humpback whales off the coast of Colombia and Ecuador show a low level of phylopatry (0.36 and 0.01 , respectively, Table 5) and a short residency, with an overall mean of 18 days and 13 days respectively (Capella et al. $1995^{1}$, Scheidat et al. 2000). Our findings indicate that the SM is a recurrent feeding ground destination for at least some of the humpback whales that breed along the coast of Colombia and is unique in the southern ocean outside of the Antarctic region (Clapham \& Mead 1999).

It is unknown whether the six individual whales described in this report are representative of the summer migratory destinations of all whales within the stock. Our results and the absence of any evidence of a migratory connection between humpback whales from WAP and the SM (Acevedo 2006), provide important and unique support for the assessment that the Strait of Magellan and its surrounding waters could be a sub-region of the feeding range of the Area I stock. This is consistent with the high level of inter-year return that we observed, also reported by Acevedo et al. (2006).

Our information and those previously published for the Antarctic Peninsula (Stone et al. 1990, Stevick et al. 2004) show that the southeastern Pacific humpback whale population may segregate into at least two separate feeding areas located at variable distances from the breeding region, resembling the north Atlantic and north Pacific humpback whale populations, where some geographically distinct feeding aggregations have been described (Baker et al. 1986, Katona \& Beard 1990, Katona \& Beard 1991, Stevick et al. 2003). Taken together, our results suggest for Area I stock the existence of a shorter migratory cycle, with final summer destinations at SM, 1,400 km closer than the previously described at WAP.

CAPELLA J, L FLÓREZ-GONZÁLEZ \& GA BRAVO (1995) Site fidelity and seasonal residence of humpback whales around Isla Gorgona, a breeding ground in the Colombian Pacific. Abstracts of the Eleventh Biennial Conference on the Biology of Marine Mammals, Orlando, Florida, USA. 
The precise migratory routes in the southeast Pacific as well as the movements within the waters of the Patagonian fjords and throughout the western Antarctic Peninsula remain poorly known. Further photographic data from the SM will be necessary to establish, with confidence, the extent of exchange among Colombia and other wintering grounds in eastern Pacific (Ecuador and Panamá). Current evidence does not allow determining the main winter destination. Based on the presence in the SM of a mtDNA haplotype absent in the SE Pacific and Antarctic Peninsula (Sabaj et al. 2004), humpback whales coming from breeding areas that have not been characterized or considered in this study could also feed in the SM (for example the SE coast of Brazil).

\section{ACKNOWLEDGMENTS}

In Chile, humpback whale research was possible thanks to the support of Whale Sound Ltda., Fundación Yubarta (WWF-project $\mathrm{N}^{\circ}$ 9L0808.07), Universidad de Magallanes (project 021500 - UMAG), Universidad Santo Tomás (project INV- 5-03-01), Universidad de Chile and Ministerio de Bienes Nacionales. We thank Instituto de Fomento Pesquero (IFOP), Whale Sound and the Office of National Parks of Colombia for their logistical support. We are grateful to Luis Bertea, Cristián Cerutti, Derek Corcoran, Daniela Droguett, Javiera Martínez, María José Pérez, Ana M. Salas and Carlos Seguel for fieldwork assistance in the SM. Also, we thank Stefan Bräger, Jaime Cárcamo, Jaime Gibbons, Sofía Guerrero, Alejandro Kush, Alfonso Martínez and Ricardo Matus for their additional field assistance. To Isabel $\mathrm{C}$. Avila, Viviana Peña, Alexander Tobón, Isabel C. Tobón, Patricia Falk, Julio Herrera, Elizabeth Hernández and Angela Recalde for helping in photographic laboratory work, cataloguing and comparing photographs used in this study. To Flavio Briones and Felipe Astorga for collaborating on sexing procedures. We conducted our study under the permits of SERNAPESCA in Chile and Ministerio de Ambiente, Vivienda y Desarrollo Territorial in Colombia. We specially thank an anonymous reviewer who critically read the manuscript and made valuable suggestions.

\section{LITERATURE CITED}

ACEVEDO JA (2006) Distribución, filopatría, residencia e identidad poblacional de las ballenas jorobadas, Megaptera novaeangliae, que se alimentan en las aguas del Estrecho de Magallanes, Chile. Tesis de Maestría, Facultad de Ciencias, Universidad de Magallanes, Punta Arenas, Chile. 119 pp.

ACEVEDO JA, A AGUAYO-LOBO \& LA PASTENE (2006) Filopatría de la ballena jorobada (Megaptera novaeangliae Borowski, 1781), al área de alimentación del Estrecho de Magallanes. Revista de Biología Marina y Oceanografía (Chile) 41: 1119.

BAKER CS, LM HERMAN, A PERRY, WS LAWTON, JM STRALEY \& JH STRALEY (1985) Population characteristics and migration of humpback whales (Megaptera novaeangliae) in southeastern Alaska. Marine Mammal Science 1: 304-323.

BAKER CS, LM HERMAN, A PERRY, WS LAWTON, JM STRALEY, AA WOLMAN, GD KAUFMAN, HE WINN, JD HALL, JM REINKE \& J OSTMAN (1986) Migratory movement and population structure of humpback whales (Megaptera novaeangliae) in central and eastern north Pacific. Marine Ecology Progress Series 31: 105-119.

BAKER CS, A PERRY, JL BANNISTER, MT WEINRICH, RB ABERNETHY, J CALAMBOKIDIS, J LIEN, RH LAMBERTSEN, J URBÁN- RAMIREZ, O VASQUEZ, P CLAPHAM, A ALLING, SJ O'BRIEN \& SR PALUMBI (1993) Abundant mitochondrial DNA variation and worldwide population structure in humpback whales. Proceedings of the National Academy of Sciences USA 90: 8239-8243.

BAKER CS, L FLÓREZ-GONZÁLEZ, B ABERNETHY, HC ROSENBAUM, RW SLADE, J CAPELLA \& JL BANNISTER (1998) Mitochondrial DNA variation and maternal gene flow among humpback whales of the Southern Hemisphere. Marine Mammal Science 14: 721-737.

BAKER CS \& L MEDRANO-GONZÁLEZ (2002) Worldwide distribution and diversity of humpback whale mitochondrial DNA lineages. In: Pfeiffer CJ (ed) Cell and molecular biology of marine mammals: 84-99. Krieger Publishing Co., Inc, Melbourne, Florida, USA.

CABALLERO S, H HAMILTON, H JARAMILLO, J CAPELLA, L FLÓREZ-GONZÁLEZ, C OLAVARRÍA-BARRERA, HC ROSENBAUM, F GUHL \& CS BAKER (2001) Genetic characterization of the Colombian Pacific coast humpback whale population using RAPD and mitochondrial DNA sequences. Memoirs of the Queensland Museum 47: 459-464.

CALAMBOKIDIS J, JC CUBBAGE, GH STEIGER, KC BALCOMB \& P BLOEDEL (1990) Population estimates of humpback whales in the Gulf of the Farallones, California. Reports of the International Whaling Commission (Special Issue) 12: 343-348.

CALAMBOKIDIS J, G STEIGER, J STRALEY, L HERMAN, S CERCHIO, D SALDEN, J URBÁN, J JACOBSEN, O VON ZIEGESAR, K BALCOMB, C GABRIELE, M DAHLHEIM, S UCHIDA, G ELLIS, Y MIYAMURA, P LADRÓN DE GUEVARA, M YAMAGUCHI, F SATO, S MIZROCH, L SCHLENDER, K RASMUSSEN, J BARLOW \& T QUINN II (2001) Movements and population structure of humpback whales in the north Pacific. Marine Mammal Science 17: 769-794. 
CLAPHAM PJ, LS BARAFF, CA CARLSON, MA CHRISTIAN, DK MATTILA, CA MAYO, MA MURPHY \& S PITTMAN (1993) Seasonal occurrence and annual return of humpback whales, Megaptera novaeangliae, in the southern Gulf of Maine. Canadian Journal of Zoology 71: 440-443.

CLAPHAM PJ \& JG MEAD (1999) Megaptera novaeangliae. Mammalian Species Number 604: $1-9$

CLARKE R (1962) Whale observation and whale marking off the coast of Chile in 1958, and from Ecuador towards and beyond the Galapagos Islands in 1959. Norsk Hvalfangst. Tidende 51: 265-287.

DARLING JD \& S CERCHIO (1993) Movement of humpback whale (Megaptera novaeangliae) between Japan and Hawaii. Marine Mammal Science 9: 84-89.

DARLING JD \& D MCSWEENEY (1985) Observations on the migrations of north Pacific humpback whales (Megaptera novaeangliae). Canadian Journal of Zoology 63: 308-314

DARLING JD, J CALAMBOKIDIS, K BALCOMB, P BLOEDEL, K FLYNN, A MOSHIZUKI, K MORI, F SATO, H SUGANUMA \& M YAMAGUCHI (1996) Movement of a humpback whale (Megapetra novaeangliae) from Japan to British Columbia and return. Marine Mammal Science 12: 281-287.

FÉLIX F \& B HAASE (2001a) The humpback whale off the coast of Ecuador, population parameters and behavior. Revista de Biología Marina y Oceanografía (Chile) 36: 61-74.

FÉLIX F \& B HAASE (2001b) A note on humpback whale off the coast of Ecuador during the 1997 "El Niño" event. Journal Cetacean Research and Management 3: 59-64.

FÉLIX F \& B HAASE (2001c) Towards an estimate of the southeastern Pacific humpback whale stock. Journal of Cetacean Research and Management 3: 55-58.

FLÓREZ-GONZÁLEZ L (1991) Humpback whales, Megaptera novaeangliae in the Gorgona Island, Colombian Pacific breeding waters: population and pod characteristics. Memoirs of the Queensland Museum 30: 291-295.

FLÓREZ-GONZÁLEZ L, J CAPELLA, B HASSE, GA BRAVO, F FÉLIX \& T GERRODETTE (1998) Changes in winter destinations and the northernmost record of southeastern Pacific humpback whales. Marine Mammal Science 14: 189-196.

GABRIELE C, J STRALEY, L HERMAN \& $R$ COLEMAN (1996) Fastest documented migration of a north Pacific humpback whale. Marine Mammal Science 12: 457-464.

GARRIGUE C, J GREAVES \& M CHAMBELLANT (2001) Characteristics of the New Caledonian humpback whale population. Memoirs of the Queensland Museum 47: 539-546.

GIBBONS J \& J CAPELLA (2006) Mamíferos marinos. En: CONAMA (eds) Biodiversidad de Chile, patrimonio y desafíos: 236-247. Editorial Ocho Libros, Santiago, Chile.

GIBBONS J, J CAPELLA, R MATUS \& L GUZMÁN (1998) Presence of humpback whales, Megaptera novaeangliae (Balaenopteridae), in the Chilean Patagonian channels. Anales del Instituto Patagonia, Serie Ciencias Naturales (Chile) 26: 6975 .

GIBBONS J, J CAPELLA \& C VALLADARES (2003) Rediscovery of a humpback whale, Megaptera novaeangliae, summering ground in the Strait of
Magellan, Chile. Journal of Cetacean Research and Management 5: 203-208

GIBBONS J, J CAPELLA \& Y VILINA (2004) Ventral fluke pigmentation of humpback whale, Megaptera novaeangliae, population at the Francisco Coloane marine park, Straits of Magellan, Chile. Anales Instituto Patagonia, Serie Ciencias Naturales (Chile) 32: 63-67.

GILL PC \& CLK BURTON (1995) Photographic resight of a humpback whale between western Australia and Antarctic area IV. Marine Mammal Science 11: 96100 .

GLOCKNER-FERRARI DA \& MJ FERRARI (1990) Reproduction in the humpback whale (Megaptera novaeangliae) in Hawaiian waters, 1975-1988: the life history, reproductive rates and behaviour of known individuals identified through surface and underwater photography. Reports of the International Whaling Commission (Special Issue) 12: $161-170$

GUERRERO S (2003) Identidad de ballenas jorobadas (Megaptera novaeangliae) del Estrecho de Magallanes y su relación con la población de jorobadas de Colombia y otras del Hemisferio Sur, basado en análisis genotípicos. Tesis de Medicina Veterinaria, Universidad Santo Tomás, Santiago, Chile. $70 \mathrm{pp}$

HALL TA (1999) BioEdit: a user-friendly biological sequence alignment editor and analysis program for Windows 95/98/NT. Nucleic Acids Symposium Series 41: 95-98.

INTERNATIONAL WHALING COMMISSION (1998) Report of the scientific committee. Annex G. Report of the sub-committee on comprehensive assessment of Southern Hemisphere humpback whales. Report of the International Whaling Commission 48: 170-182.

KATONA S \& JA BEARD (1990) Population size, migrations and feeding aggregations of the humpback whale (Megaptera novaeangliae) in the western north Atlantic Ocean. Reports of the International Whaling Commission (Special Issue) 12: 295-305

KATONA S \& JA BEARD (1991) Humpback whale (Megaptera novaeangliae) in the western north Atlantic Ocean. Memoirs of the Queensland Museum 30: 307-321.

KATONA S \& H WHITEHEAD (1981) Identifying humpback whales using their natural markings. Polar Record 20: 439-444.

KAUFMAN GD, MG OSMOND, AJ WARD \& PH FORESTELL (1990) Photographic documentation of the migratory movement of a humpback whale (Megaptera novaeangliae) between east Australia and Antarctic area V. Report of International Whaling Commission (Special Issue) 12: 265-267.

LAMBERTSEN RH (1987) A biopsy system or large whales and its use for cytogenetics. Journal of Mammalogy 68: 443-445.

MACKINTOSH NA (1942) The southern stocks of whalebone whales. Discovery Reports 22: 197-300.

MACKINTOSH NA (1965) The stocks of whales. The Buckland Foundation, Coward \& Gerrish Ltd., Larkhall, Bath, United Kingdom. 232 pp.

MATE B, R GISINER \& R MOBLEY JR (1998) Local and migratory movements of Hawaiian humpback whales tracked by satellite telemetry. Canadian Journal of Zoology 76: 863-868.

OLAVARRÍA-BARRERA C (1999) Identidad genética de las ballenas jorobadas (Megaptera novaeangliae 
Borowski, 1781) en las aguas adyacentes a la península Antártica. Tesis para optar al grado de Licenciado y al Título profesional de Biólogo Marino, Facultad de Ciencias del Mar, Universidad de Valparaíso, Valparaíso, Chile. 62 pp.

OLAVARRÍA-BARRERA C, CS BAKER, L MEDRANO, A AGUAYO, S CABALLERO, L FLÓREZGONZÁLEZ, J CAPELLA, HC ROSENBAUM, C GARRIGUE, J GREAVES, JL BANNISTER, M JENNER \& C JENNER (2000) Stock identity of Antarctic Peninsula humpback whales inferred from MtDNA variation. Paper SC/ 52/IA 15 submitted to the Scientific Committee of the International Whaling Commission, 2000.

OMURA H (1953) Biological study on humpback whales in the Antarctic whaling areas IV and V. Scientific Report of Whales Research Institute 8: 81-102.

PALSBØLL PJ, I BAKKE, M EL-GEWELY \& A VADER (1992) Determination of gender in cetacean by polymerase chain reaction. Canadian Journal of Zoology 70: 2166-2170.

PERRY A, CS BAKER \& LM HERMAN (1990) Population characteristics of individually identified humpback whales in the central and eastern north Pacific: a summary and critique. Reports of the International Whaling Commission (Special Issue) 12: $307-317$

RECALDE A (2005) Movimientos de la ballena jorobada (Megaptera novaeangliae) entre dos zonas del Pacífico colombiano: el Parque Nacional Natural Gorgona y la Bahía de Málaga. Trabajo de grado, Facultad de Ciencias, Pontificia Universidad Javeriana, Bogotá, Colombia. 49 pp.

ROZEN S \& H SKALETSKY (2000) Primer3 on the WWW for general users and for biologist programmers. In: Krawetz S \& S Misener (eds) Bioinformatics methods and protocols: methods in molecular biology: 365-386. Human Press, Totowa, New York, USA.

SABAJ V, Y VILINA, S GUERRERO, J CAPELLA, J GIBBONS \& C VALLADARES (2004) Genetic structure of the recently discovered feeding ground of Humpback whales at Straits of Magellan, Chile. Paper SC/56/SH19 submitted to the Scientific Committee of the International Whaling Commission, Sorrento, June 2004. 9pp.

SAIKI RK, DH GELFAND, S STOFELL, R SCHARF, R HIGUCHI, GT HORN, KB MULLIS \& HA ERLICH (1988) Primer-directed enzymatic amplification of DNA with a thermostable DNA polymerase. Science 239: 487-491.

SCHEIDAT $\mathrm{M}, \mathrm{C}$ CASTRO, J DENKINGER, J GONZÁLEZ \& D ADELUNG (2000) A breeding area for humpback whales (Megaptera novaeangliae) off Ecuador. Journal of Cetacean Research and Management 2: 165-171.

SMITH T, J ALLEN, P CLAPHAM, P HAMMOND, S KATONA, F LARSEN, J LIEN, D MATTILA, P PALSBØLL, J SIGURJÓNSSON, P STEVICK \& N OIEN (1999) An ocean-wide mark-recapture study of the north Atlantic humpback whale (Megaptera novaeangliae). Marine Mammal Science 15: 1-32.

STEIGER GH, J CALAMBOKIDIS, R SEARS, KC BALCOMB \& JC CUBBAGE (1991) Movement of humpback whales between California and Costa Rica. Marine Mammal Science 7: 306-310.

STEVICK PT, A AGUAYO, J ALLEN, IC AVILA, J CAPELLA, C CASTRO, K CHATER, M H ENGEL, F FELIX, L FLÓREZ-GONZÁLEZ, A FREITAS, B HAASE, M LLANO, L LODI, E MUNOZ, C OLAVARRÍA-BARRERA, E SECCHI, M SCHEIDAT \& S SICILIANO (2004) A note on the migrations of individually identified humpback whales between the Antarctic Peninsula and South America. Journal of Cetacean Research and Management 6: 109-113.

STEVICK PT, J ALLEN, PJ CLAPHAM, SK KATONA, F LARSEN, J LIEN, DK MATTILA, PJ PALSBØLL, J ROBBINS, J SIGURJANSSON, TD SMITH \& PS HAMMOND (2003) Segregation of migration by feeding ground origin in north Atlantic humpback whales (Megaptera novaeangliae). Journal of Zoology London 259: 231-237.

STEVICK PT, N OIEN \& DK MATTILA (1998) Migration of a humpback whale (Megaptera novaeangliae) between Norway and the West Indies. Marine Mammal Science 14: 162-166.

STONE GS, L FLÓREZ-GONZÁLEZ \& S KATONA (1990) Whale migration record. Nature 346: 705

TOWNSEND CH (1935) The distribution of certain whales as shown by the logbook records of American whaleships. Zoologica 19: 1-50.

URBÀN J, C ALVAREZ-F, M SALINAS-Z, J JACOBSEN, KC BALCOMB, L JARAMILLO, P LADRÓN DE GUEVARA-P \& A AGUAYO-L (1999) Population size of the humpback whale, Megaptera novaeangliae, in waters off the Pacific coast of Mexico. Fishery Bulletin 97: 1017-1024

URBÁN-R, A JARAMILLO-L, A AGUAYO-L, P LADRÓN DE GUEVARA-P, M SALINAS-Z, C ALVAREZ-F, L MEDRANO-G, JK JACOBSEN, KC BALCOMB, DE CLARIDGE, J CALAMBOKIDIS, GH STEIGER, JM STRALEY, O VON ZIEGESAR, JM WAITE, S MIZROCH, ME DAHLHEIM, JD DARLINGY \& CS BAKER (2000) Migratory destinations of humpback whales wintering in the Mexican Pacific. Journal of Cetacean Research and Management 2: 101-111.

WITTEVEEN BH, JM STRALEY, O VON ZIEGESAR, D STEEL \& CS BAKER (2004) Abundance and mtDNA differentiation of humpback whales (Megaptera novaeangliae) in the Shumagin islands, Alaska. Canadian Journal of Zoology 82: 1352-1359.

ZERBINI, AN, A ANDRIOLO, MP HEIDE-JORGENSEN, JL PIZZORNO, YG MAIA, GR VAN BLARICOM, DP DEMASTER, PC SIMOES-LOPES, S MOREIRA \& C BETHLEM (2006) Satellite-monitored movements of humpback whales Megaptera novaeangliae in the southwest Atlantic Ocean. Marine Ecology Progress Series 313: 295-304. 